\title{
DNA methylation affects cell proliferation, cortisol secretion and steroidogenic gene expression in human adrenocortical $\mathrm{NCl}-\mathrm{H} 295 \mathrm{R}$ cells
}

\author{
J Liu' ${ }^{1}$, X-D Liं ${ }^{2}$ A Vaheri ${ }^{2}$ and R Voutilainen ${ }^{1,3}$ \\ ${ }^{1}$ Department of Pathology, Haartman Institute, University of Helsinki, FIN-00014 Helsinki \\ ${ }^{2}$ Department of Virology, Haartman Institute, University of Helsinki, FIN-00014 Helsinki \\ ${ }^{3}$ Department of Pediatrics, Kuopio University Hospital and University of Kuopio, FIN-70211 Kuopio, Finland
}

(Requests for offprints should be addressed to J Liu; Email: Jiangi.Liu@ helsinki.fi)

\begin{abstract}
Aberrant DNA methylation may be involved in human adrenocortical tumorigenesis, which is often accompanied by abnormal hormone production. In this study, we aimed to clarify the effects of DNA methylation on steroidogenesis using the human adrenocortical $\mathrm{NCl}-\mathrm{H} 295 \mathrm{R}$ cell line as a model. Treatment with the DNA methylation inhibitor 5-aza-2'-deoxycytidine (Azad; $10 \mu \mathrm{M}$ for 7 days) decreased the proliferation rate to approximately $20 \%$ and the cell number to $60 \%$ of the control, with a simultaneous increase in the expression of the cyclin-dependent kinase inhibitor $\mathrm{p} 57^{\mathrm{KIP} 2}$ gene. In addition, Azad treatment increased cortisol secretion dose and time dependently, whereas dehydroepiandrosterone sulfate secretion was not affected. Azad treatment decreased basal and $(\mathrm{Bu})_{2} \mathrm{CAMP}$-induced expression of low- and high-density lipoprotein receptor, steroidogenic acute regulatory protein (StAR), cholesterol side-chain cleavage enzyme, steroid $17 \alpha$-hydroxylase/17,20-lyase and steroid 21 -hydroxylase mRNA, as well as the StAR protein level. In contrast, Azad treatment increased the basal expression of steroid $11 \beta$-hydroxylase and $3 \beta$-hydroxysteroid dehydrogenase $/ \Delta^{5}-\Delta^{4}$-isomerase genes, although it inhibited the $(\mathrm{Bu})_{2} \mathrm{CAMP}$-induced expression of these two genes. The expression of steroidogenic factor-1 (SF-1) and DAX-1 (dosage-sensitive sex reversal-adrenal hypoplasia congenita critical region on the X-chromosome 1) genes (both harboring putative $\mathrm{CpG}$ islands in their promoters) and the methylation degree of the Hpall recognition site(s) in the SF-1 gene promoter region were reduced by Azad treatment. The immunostaining pattern of the methyl-CpG-binding protein MeCP2 was also modified by Azad treatment. These results suggest that DNA methylation may be implicated in the regulation of cell proliferation and steroidogenesis in human adrenocortical cells.
\end{abstract}

Journal of Molecular Endocrinology (2004) 33, 651-662

\section{Introduction}

Modification of DNA by cytosine methylation is an important mechanism of epigenetic regulation of genomic functions (Zingg \& Jones 1997, Jaenisch \& Bird 2003). DNA methylation patterns are mosaics in various cell and tissue types of an organism. These cell- and tissue-specific methylation patterns are a result of an ordered demethylation and re-methylation process that occurs during development. Once a given sequence becomes methylated, it then becomes a target for the binding of a methylCpG-binding protein (MeCP), such as MeCP2. The binding of MeCPs can induce changes in the surrounding chromatin to affect gene transcription by interfering with the actions of transcription factors (Wade 2001, Prokhortchouk \& Hendrich 2002). It is believed that activation of cell lineagedetermining genes leads to activation and maintenance of a cell-type-specific network of gene expression. The genes involved in this determination are tightly regulated so that any expression of these genes is prevented in a different cell lineage. Celltype-specific DNA methylation could be involved in establishing or maintaining the expression pattern of these determinative genes and thus contribute to the stability of a specific differentiation state (Zingg \& Jones 1997, Jaenisch \& Bird 2003). 
In adrenocortical cells, steroid hormone production is controlled at two levels, i.e. substrate mobilization for acute control and gene transcription for long-term regulation of steroidogenesis. Cholesterol, taken up by low- or high-density lipoprotein receptors (LDL receptor or CLA-1 respectively), is first transported to the inner mitochondrial membrane by the steroidogenic acute regulatory protein (StAR) and converted to pregnenolone by P450 scc (cholesterol side-chain cleavage enzyme). Production of steroid hormones in human adrenals is zonally and developmentally regulated. Pregnenolone may be hydroxylated to $17 \alpha$-hydroxypregnenolone and further cleaved to dehydroepiandrosterone (DHEA) by P450c17 (steroid 17 $\alpha$-hydroxylase/17,20-lyase), augmented by cytochrome b5. Pregnenolone and $17 \alpha-$ hydroxypregnenolone are also metabolized to aldosterone and cortisol respectively, via successive reactions of $3 \beta$-hydroxysteroid dehydrogenase/ $\Delta^{5}-\Delta^{4}$-isomerase (3$\beta$-HSD), steroid 21 -hydroxylase $(\mathrm{P} 450 \mathrm{c} 21)$ and steroid $11 \beta$-hydroxylase (P450c11) or aldosterone synthase (P450c18). Two orphan members of the nuclear receptor superfamily, steroidogenic factor-1 (SF-1) and DAX-1 (dosagesensitive sex reversal-adrenal hypoplasia congenita critical region on the $\mathrm{X}$-chromosome 1), have been shown to play a central role in adrenocortical morphogenesis and in mediating transcriptional regulation of the steroidogenic genes (Mesiano \& Jaffe 1997, Miller et al. 1997, Peter \& Dubuis 2000).

The contribution of DNA methylation to the steroidogenic activity of adrenocortical cells has not been studied much. The methylation level of specific $\mathrm{CpG}$ sites in the 5'-flanking region of the P450c17 gene was positively correlated with P450c17 expression when compared in bovine adrenal cortex, cultured adrenocortical cells and fibroblasts, but not when compared in different bovine adrenocortical zones and white blood cells, suggesting that the methylation status of the P450c17 gene is not always related to its transcription (Hornsby et al. 1991, 1992). In contrast, the promoter methylation status of the $\mathrm{P} 450 \mathrm{c} 21$ gene is inversely associated with its expression level in mouse adrenocortical Y-1 and normal mouse adrenocortical cells, and suppression of methyltransferase mRNA expression reduces the methylation degree but activates P450c21 expression in Y-1 cells and in transplanted Y-1 tumors. Nevertheless, the DNA methylation inhibitor 5-azacytidine cannot recover the expression of the $\mathrm{P} 450 \mathrm{c} 21$ gene even though the methylation degree of the gene is reduced. In addition, loss of P450c21 expression temporally precedes the extensive methylation of the transfected $\mathrm{P} 450 \mathrm{c} 21$ gene in $\mathrm{Y}-1$ cells, indicating that methylation may not be the principal cause of $\mathrm{P} 450 \mathrm{c} 21$ gene repression in this cell line (Szyf et al. 1990, Ramchandani et al. 1997).

Altered hormone production is often observed in human adrenocortical tumors (Dackiw et al. 2001, $\mathrm{Ng}$ \& Libertino 2003), which have aberrant DNA methylation. In normal and pathological adrenocortical tissues, the H19 promoter methylation correlated negatively with the tumor suppressor $\mathrm{H} 19$ and positively with the nearby insulin-like growth factor-II (IGF-II) gene expression. A DNA methylation inhibitor 5-aza-2'-deoxycytidine (Azad) reduced proliferation of human adrenocortical cell line NGI-H295R (H295R) cells, probably on the basis of the induction of $\mathrm{H} 19$ and reduction of IGF-II gene expression (Gao et al. 2002). Azad incorporates into newly synthesized DNA and then inhibits DNA methylation. Thus, it has been widely used to demonstrate the association between methylation in specific gene regions and the expression of the associated genes (Christman 2002). A number of experiments have shown that altering DNA methylation patterns with Azad can change the differentiation state of cells (Zingg \& Jones 1997). As knowledge about the effects of DNA methylation on steroidogenesis could increase our understanding of the precisely controlled gene expression during adrenocortical differentiation and tumorigenesis, we studied the effect of Azad on cortisol secretion and expression of steroidogenic genes in H295R cells.

\section{Materials and methods}

\section{Cell cultures}

H295R cells obtained from American Type Culture Collection (ATCG, Rockville, MD, USA) were grown in a 1:1 mixture of Dulbecco's modified Eagle's medium and Ham's F12 medium (Sigma) supplemented with 1\% Insulin, Transferrin and Selenite (ITS) +1 liquid media supplement (Sigma), 2\% Ultroser SF (Biosepra, Marlborough, MA, USA), $2 \mathrm{mM}$ L-glutamine (Gibco) and antibiotics $(125 \mu \mathrm{g} / \mathrm{ml}$ streptomycin and 125 $\mathrm{IU} / \mathrm{ml}$ penicillin; Orion Pharmaceutical Co., 
Espoo, Finland) at $37^{\circ} \mathrm{C}$ in a $5 \% \mathrm{CO}_{2}$ atmosphere. The medium was changed every other day and the cells were split at a ratio of 1:3 with trypsin after reaching confluence. Treatment with Azad and $(\mathrm{Bu})_{2} \mathrm{cAMP}$ (both from Sigma) was initiated on the second day after reseeding of the cells. Triplicate dishes were used for the experiments that were repeated at least three times. Trypan blue exclusion was routinely used to monitor cell viability.

\section{Hormone measurements}

Cortisol was measured from conditioned cell culture media with the Technicon Immuno 1 system (Bayer). This method is a magnetic separation competitive enzyme immunoassay (Letellier et al. 1996) with a detection limit of $20 \mathrm{nM}$. The intra- and interassay coefficients of variation were $<4$ and $<6 \%$ respectively. Dehydroepiandrosterone sulfate (DHEA-S) was analyzed by competitive enzyme immunoassays with measurement kits from Diagnostic System Laboratories (Webster, TX, USA; product code DSL-10-3500). The detection limit of the DHEA-S assay was $40.7 \mathrm{nM}$. The intra- and interassay coefficients of variation were $5 \cdot 1$ and $7 \cdot 2 \%$ respectively.

\section{RNA analysis}

Cytoplasmic RNA was extracted from the H295R cells as previously described (Voutilainen et al. 1986, Ilvesmäki \& Voutilainen 1991). PolyA ${ }^{+}$ mRNA was prepared from the cytoplasmic RNA with Oligotex mRNA Spin-Column (Qiagen) according to the manufacturer's instructions. The cytoplasmic RNA or polyA ${ }^{+}$mRNA was analyzed by Northern blotting and the membranes were hybridized with cDNA or oligonucleotide probes as reported previously (Ilvesmäki \& Voutilainen 1991, Liu et al. 1996). The probes for $\mathrm{p} 57^{\mathrm{KIP} 2}$ (Liu et al. 1997), LDL receptor, CLA-1 (Liu et al. 2000), StAR (Liu et al. 1996), P450 scc, P450c17, P450c21, P450c11, $\gamma$-actin (Ilvesmäki \& Voutilainen 1991) and 3 $\beta$-HSD (Voutilainen et al. 1991) were the same as described previously. Additional $30 \mathrm{mer}$ oligonucleotide probes were used to detect SF-1, DAX-1 and cytochrome b5 mRNAs in Northern hybridization analyses. The oligonucleotide sequences were 5'-TCA GGC ACT TCT GGA AGG GGG AGA AGG GAC-3' for SF-1 (GenBank accession no. D84207), 5'-AGA AAG
CAC TTG ATG GGT TGG ACG TGG GAG-3' for DAX-1 (GenBank accession no. U31929) and 5'-ATG GCA GGG ATG ACG CAG TTG GTG CAG CAA-3' for cytochrome b5 (GenBank accession no. BC015182) mRNAs. The relative intensities of the autoradiographic signals were quantified by densitometric scanning. All RNA data from Northern blotting prepared with cytoplasmic or polyA ${ }^{+}$RNA shown here were normalized with the respective $28 \mathrm{~S}$ ribosomal RNA or $\gamma$-actin mRNA values.

\section{PCR-based methylation analysis}

PCR-based methylation analysis (Gao et al. 2002) was used to analyze the SF-1 promoter and exon 1 area (GenBank accession no. D84206) which contains numerous HpaII/MspI recognition sequences CCGG. Briefly, genomic DNA (500 ng) was first digested for $2 \mathrm{~h}$ with $10 \mathrm{U}$ EcoRI and HpaII (methylation sensitive) or MspI (methylation insensitive) enzymes (Boehringer Mannheim) according to the manufacturer's recommendations. Optimal PGR conditions with a clean 383 bp PGR product from undigested genomic DNA but no product from MspI-digested DNA were found by: denaturing at $95^{\circ} \mathrm{C}$ for $5 \mathrm{~min} ; 35$ cycles of $95^{\circ} \mathrm{C}$ for $60 \mathrm{~s}, 65^{\circ} \mathrm{C}$ for $30 \mathrm{~s}$ and $72{ }^{\circ} \mathrm{C}$ for $45 \mathrm{~s}$; and then final extension at $72{ }^{\circ} \mathrm{C}$ for $10 \mathrm{~min}$. The PGR reaction volume was $20 \mu \mathrm{l}$, containing $0.2 \mathrm{mM}$ of each dNTP, $0.5 \mu \mathrm{M}$ of each primer, $1 \times$ reaction buffer, $2.5 \mathrm{mM} \mathrm{MgCl}_{2}$, $1.5 \mathrm{U}$ Taq DNA polymerase (Fermentas Tamro Corporation, Vantaa, Finland) and $50 \mathrm{ng}$ template DNA. The primer set was 5'-TGA GGG CGG AGA TAG ATA GG-3' (forward) and $5^{\prime}$-aag gag get ggc cat tag ag-3' (reverse). IGF-II exon 9 was used as an internal control for the DNA amount because this region has no HpaII/MspI cutting site (Gao et al. 2002). The PCR products were resolved on $2 \%$ agarose gels. PCR-based analyses were performed at least twice to ensure reproducibility of the results.

\section{Flow cytometric analysis}

Flow cytometric analysis was performed on cells treated with Azad. The cells were trypsinized, collected into $70 \%$ ethanol and stained with propidium iodide. DNA content was analyzed by a flow cytometer. Cell cycle analysis was performed 
using the Sync Wizard Model of ModFit LT software.

\section{Immunocytochemical staining}

For immunocytochemistry, H295R cells were cultured on two-well chamber plastic slides. The proliferation was demonstrated with a commercial cell proliferation kit (Amersham) to detect 5-bromo-2'-deoxyuridine (BrdU) incorporation into the replicating DNA. MeCP2 was detected with a polyclonal antibody (Upstate Ltd, Milton Keynes, UK). During the staining, the primary antibody diluted at 1:100 was added to the culture slides in PBS and incubation was performed overnight at $4{ }^{\circ} \mathrm{C}$. The slides were then incubated with biotin-conjugated secondary antibody from the ABC-Elite kit (Vector Laboratories, Burlingame, CA, USA), and thereafter with ABC solution according to the manufacturer's instructions. Finally, light counterstaining was performed with hematoxylin, and the slides were dehydrated and mounted. For the negative control, the primary antibody was replaced with normal rabbit serum or PBS alone. To exclude the effect of possible endogenous biotin, biotin blocking (avidin-biotin blocking kit, Vector Laboratories) was performed before the addition of the primary antibody. The culture area was photographed and the nuclei were counted from each culture chamber. The positive staining percentage was calculated on the basis of positively stained nuclei relative to all cells.

\section{Western blotting}

Cells grown on $10 \mathrm{~cm}$ plates were collected and lysed with $160 \mu \mathrm{l}$ protein sample buffer $(63.5 \mathrm{mM}$ Tris- $\mathrm{HCl}, \mathrm{pH} 6 \cdot 8,10 \%$ glycerol, $2 \% \mathrm{SDS}, 0 \cdot 01 \%$ bromophenol blue). The mixture was sonicated briefly on ice and the total protein concentration in the supernatant was determined by the standard BCA protein assay kit (Pierce Boston Technology, Woburn, MA, USA). Subsequently, $4 \mu \mathrm{l}$ $\beta$-mercaptoethanol were added to each sample before heating at $95{ }^{\circ} \mathrm{C}$ for $5 \mathrm{~min}$. Twenty-five micrograms of total protein were loaded to each lane and separated in 10\% SDS-PAGE. Nonspecific binding was minimized by blocking with $5 \%$ non-fat milk in PBS-0.05\% Tween 20. The membrane was then incubated with StAR (ABR Affinity BioReagents, Golden, CO, USA) and
MeCP2 antibodies. The secondary antibody was a horseradish peroxidase-conjugated polyclonal antibody (DAKO, Glostrup, Denmark) and the immunoblots were developed with ECL films (Amersham). Monoclonal anti-actin antibody from Sigma (recognizing all actin isoforms) was used to control the protein loading.

\section{Statistical analyses}

The non-parametric Kruskal-Wallis test was used to reveal differences in cortisol secretion, the expression levels of the steroidogenic genes and the methylation status among the differently treated groups of H295R cells. If significant differences were found, the Mann-Whitney $U$ test was subsequently used for statistical evaluation. The Mann-Whitney $U$ test was also used to evaluate the changes in the proliferation of the cultured cells. The level of significance was chosen as $P<0 \cdot 05$.

\section{Results}

Azad treatment reduced BrdU incorporation into H295R cells. This reduction was detectable from the 72-h time point and was maintained for at least 2 weeks when Azad was used at the concentration of $10 \mu \mathrm{M}$. At the 7-day time point Azad treatment $(10 \mu \mathrm{M})$ reduced the proliferation rate to approximately $20 \%$ of the control (mean \pm S.E. of proliferation percentage, $7 \cdot 7 \pm 2 \cdot 8 \%$ for the treated cells and $41 \cdot 7 \pm 11 \%$ for the controls, $n=5$, $P<0 \cdot 01)$. Direct cell counting showed decreased cell number in Azad-treated cultures (approximately $60 \%$ of the controls at the 7 -day time point). In addition, Azad treatment enlarged the nuclear size, as analyzed by immunocytochemistry. To confirm this finding, we used flow cytometric analysis to measure the DNA content of the cell nuclei (Fig. 1a). Under normal growth conditions for 6 days after reseeding of the cells, about $60 \%$ of the H295R cells were in $\mathrm{G}_{0} / \mathrm{G}_{1}$ phase, and only $17 \%$ were in $\mathrm{G}_{2} / \mathrm{M}$ phase. In contrast, about $40 \%$ of the cells were in $\mathrm{G}_{2} / \mathrm{M}$ phase after 6 days of sustained treatment with Azad $(10 \mu \mathrm{M})$, and the fraction of the $\mathrm{G}_{0} / \mathrm{G}_{1}$ cells decreased down to $43 \%$. The fraction of S-phase cells was also reduced by about $10 \%$ with the Azad treatment. The average DNA content of the cells was increased by Azad 


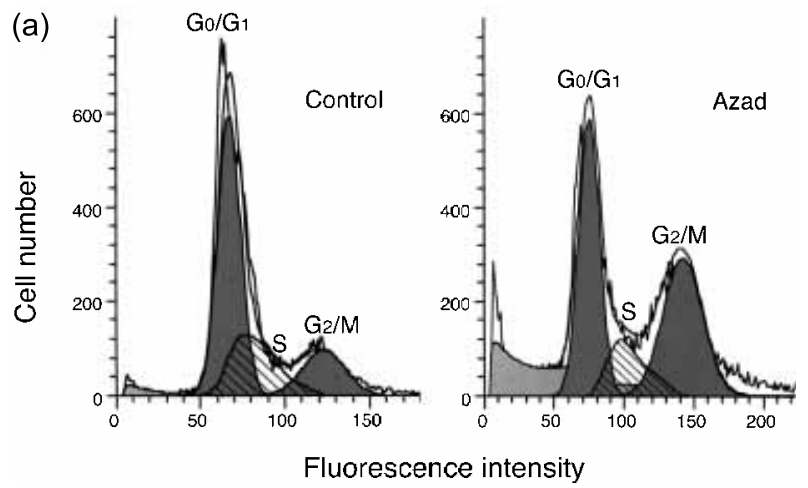

(b) $\quad \underline{0} \quad \underline{10} \quad 1 \quad \underline{0.1} \underline{0.01} \underline{0.001} \quad \operatorname{Azad}(\mu \mathrm{M})$

$--28 S$

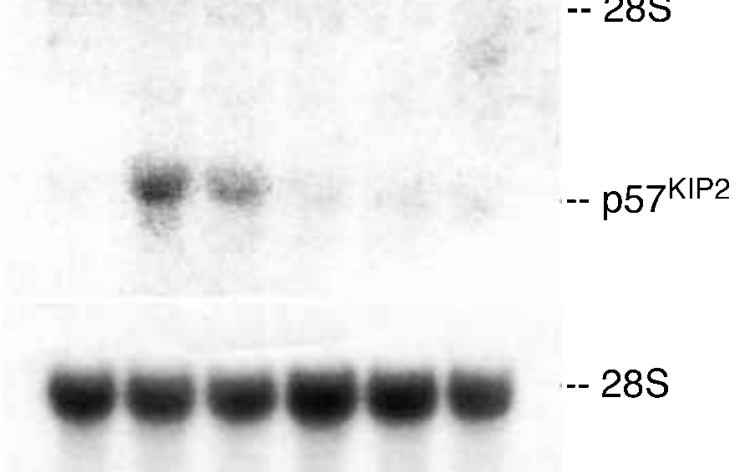

Figure 1 Induction of cell cycle arrest by Azad treatment (10 $\mu \mathrm{M}$ for 7 days) in H295R cells.

(a) Histogram showing DNA content measured by propidium iodide staining and flow cytometric analysis.

The $\mathrm{G}_{\mathrm{o}} / \mathrm{G}_{1}, \mathrm{~S}$ and $\mathrm{G}_{2} / \mathrm{M}$ phases are indicated.

(b) Representative Northern blot analysis of p57KIP2 mRNA expression after treatment with Azad at the indicated concentrations. Migration position of $28 \mathrm{~S}$ ribosomal RNA is marked in the upper panel. The same membrane was rehybridized with $28 \mathrm{~S}$ ribosomal RNA cDNA probe to show equal loading (lower panel).

treatment in $\mathrm{G}_{0} / \mathrm{G}_{1}, \mathrm{G}_{2} / \mathrm{M}$ and $\mathrm{S}$ phases by about 12,16 and $27 \%$ respectively. The cell viability after treatment with Azad $(10 \mu \mathrm{M})$ for 7 days remained at more than $98 \%$, as measured by trypan blue exclusion analysis. Higher doses of Azad induced cell death (data not shown). We further studied the effect of Azad on the expression of the cyclindependent kinase inhibitor p57 $7^{\mathrm{KIP} 2}$ gene, which is often lost in malignant adrenocortical tumors (Liu et al. 1997). In agreement with a previous report on various hematological cell lines (Li et al. 2002), Azad treatment increased the accumulation of p57 KIP2 mRNA in H295R cells (Fig. 1b).

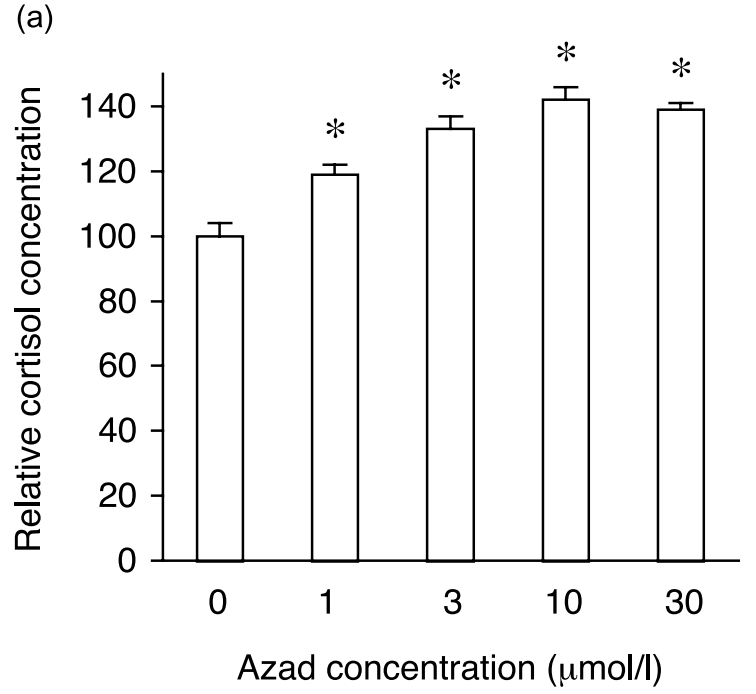

(b)

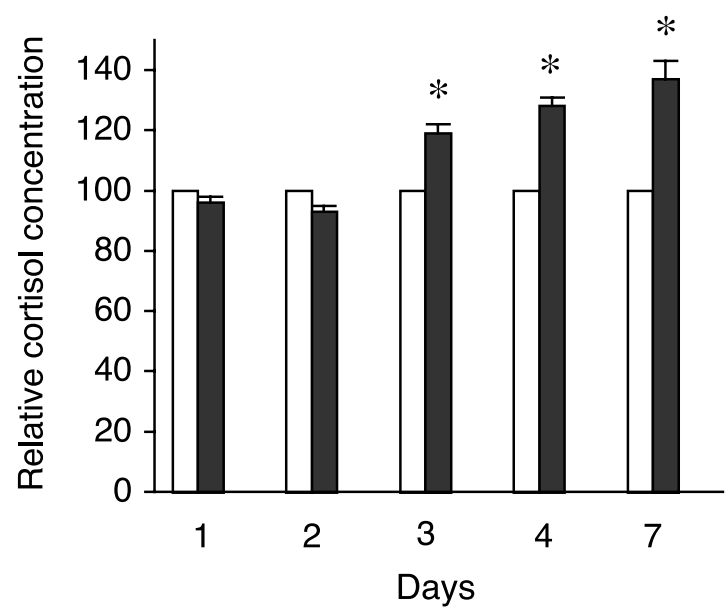

Figure 2 The effect of Azad on cortisol secretion in H295R cells. (a) Dose-dependent effect of Azad after 7 days of incubation. (b) Time-dependent effect of Azad $(10 \mu \mathrm{M})$. Open and filled columns represent cortisol secretion from control and Azad-treated cultures respectively. Cortisol concentrations were normalized by the protein contents of the corresponding cells. Each column represents the relative mean \pm S.E. of three experiments, with the control values adjusted to 100 . ${ }^{*} P<0.01$ compared with the control.

To characterize the effect of Azad on steroidogenesis in H295R cells, we first measured cortisol concentration from the conditioned media. The basal steroid secretion depended on the cell number and culture time, with the cortisol production $36 \cdot 1 \pm 3.5 \mathrm{nmol} / \mathrm{mg} \quad$ DNA and DHEA-S $16 \cdot 9 \pm 1 \cdot 1 \mathrm{nmol} / \mathrm{mg}$ DNA during 1 day 
Table 1 The effect of Azad $(10 \mu \mathrm{M})$ and $(\mathrm{Bu})_{2} \mathrm{CAMP}(1 \mathrm{mM})$ treatments (for 7 days) on the production of cortisol and DHEA-S in H295R cells

\begin{tabular}{|c|c|c|c|c|}
\hline & Control & $(\mathrm{Bu})_{2} \mathrm{CAMP}$ & Azad & $(\mathrm{Bu})_{2}$ CAMP/Azad \\
\hline $\begin{array}{l}\text { Cortisol } \\
\text { DHEA-S }\end{array}$ & $\begin{array}{l}100 \pm 6 \\
100 \pm 11\end{array}$ & $\begin{array}{c}3415 \pm 238^{\star *} \\
135 \pm 8^{*}\end{array}$ & $\begin{array}{c}142 \pm 9^{\star \star} \\
86 \pm 9\end{array}$ & $\begin{array}{c}2581 \pm 111^{\star * \#} \\
133 \pm 8^{*}\end{array}$ \\
\hline
\end{tabular}

The values represent the means \pm S.E. from six experiments, with the controls adjusted to 100 . ${ }^{*} P<0 \cdot 05$; ${ }^{\star \star} P<0.01$ as compared with the control; ${ }^{\#} P<0.01$ as compared with the $(\mathrm{Bu})_{2} \mathrm{cAMP}$ group.

of culture. As the absolute steroid values do not have any particular significance for the regulatory effect of Azad, we expressed steroid concentrations as percentages of the respective control in each experiment. As shown in Fig. 2, Azad treatment increased cortisol secretion in a dose- and time-dependent manner. Since the cell number was decreased during Azad treatment, the increased cortisol concentration means enhanced cortisol secretion from individual cells. In contrast, DHEA-S secretion was not significantly affected by Azad treatment. In addition, $(\mathrm{Bu})_{2} \mathrm{cAMP}$ increased cortisol secretion dose and time dependently (data not shown), and this stimulatory effect of $(\mathrm{Bu})_{2} \mathrm{cAMP}$ was inhibited by pre- or co-treatment with Azad for 1 week (Table 1, and data not shown). DHEA-S secretion was also increased by $(\mathrm{Bu})_{2} \mathrm{CAMP}$ (1 mM for 7 days) incubation by about $35 \%$, and this stimulatory effect was not affected by co-treatment with Azad (Table 1). Androstenedione secretion behaved similarly to that of DHEA-S in these experiments (data not shown).
In order to clarify the mechanism underlying the increased cortisol secretion during Azad treatment, we studied the expression of steroidogenic genes with Northern blot analyses. Unexpectedly, Azad treatment decreased basal and $(\mathrm{Bu})_{2} \mathrm{cAMP}$-induced LDL receptor, CLA-1, StAR, P450 scc, P450c17 and P450c21 mRNA expression (Fig. $3 a$ and $b$ ). Since StAR controls the rate-limiting step in steroidogenesis (Christenson \& Strauss 2001), we measured StAR protein levels by Western blot analysis to find out if the mRNA and protein levels behave similarly after Azad treatment. As shown in Fig. $3 c$, the basal and $(\mathrm{Bu})_{2} \mathrm{cAMP}-$ induced StAR protein (including the $37 \mathrm{kDa}$ preprotein and $30 \mathrm{kDa}$ mature protein) levels were reduced by Azad treatment $(P<0 \cdot 05, n=4)$. The reduction of StAR mRNA accumulation by Azad treatment was time dependent (Fig. 3d), with the earliest statistically significant effect detected after 5 days of the treatment. Interestingly, Azad treatment slightly induced the basal expression of P450c11 and 3 $\beta$-HSD mRNAs, but inhibited

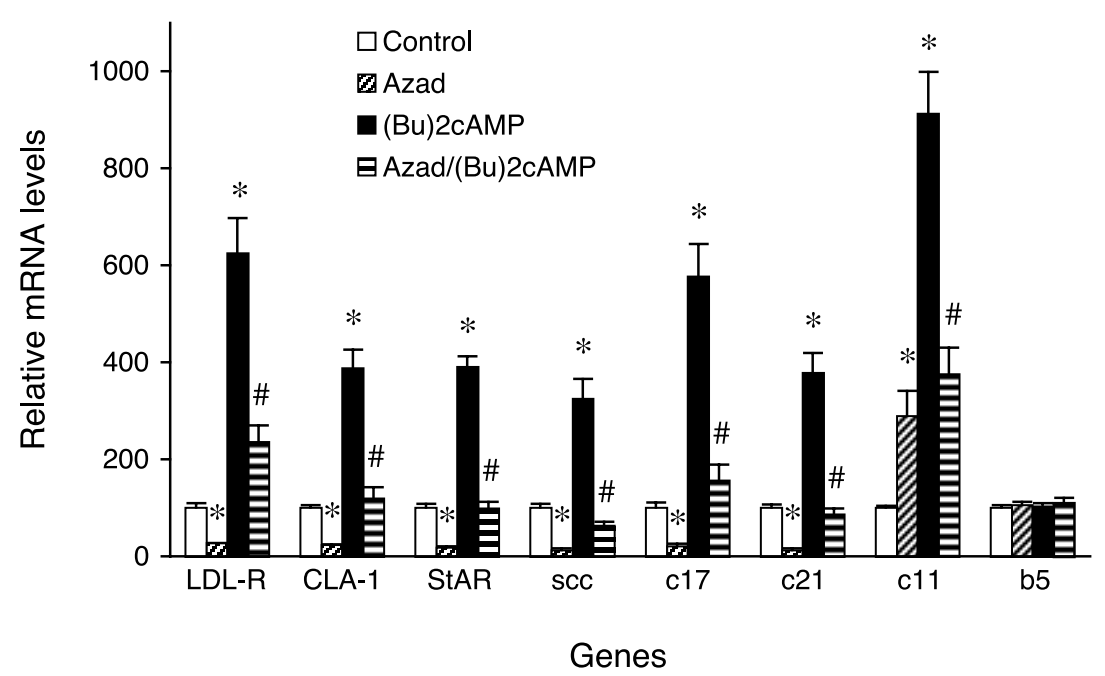

Figure 3 (a). 


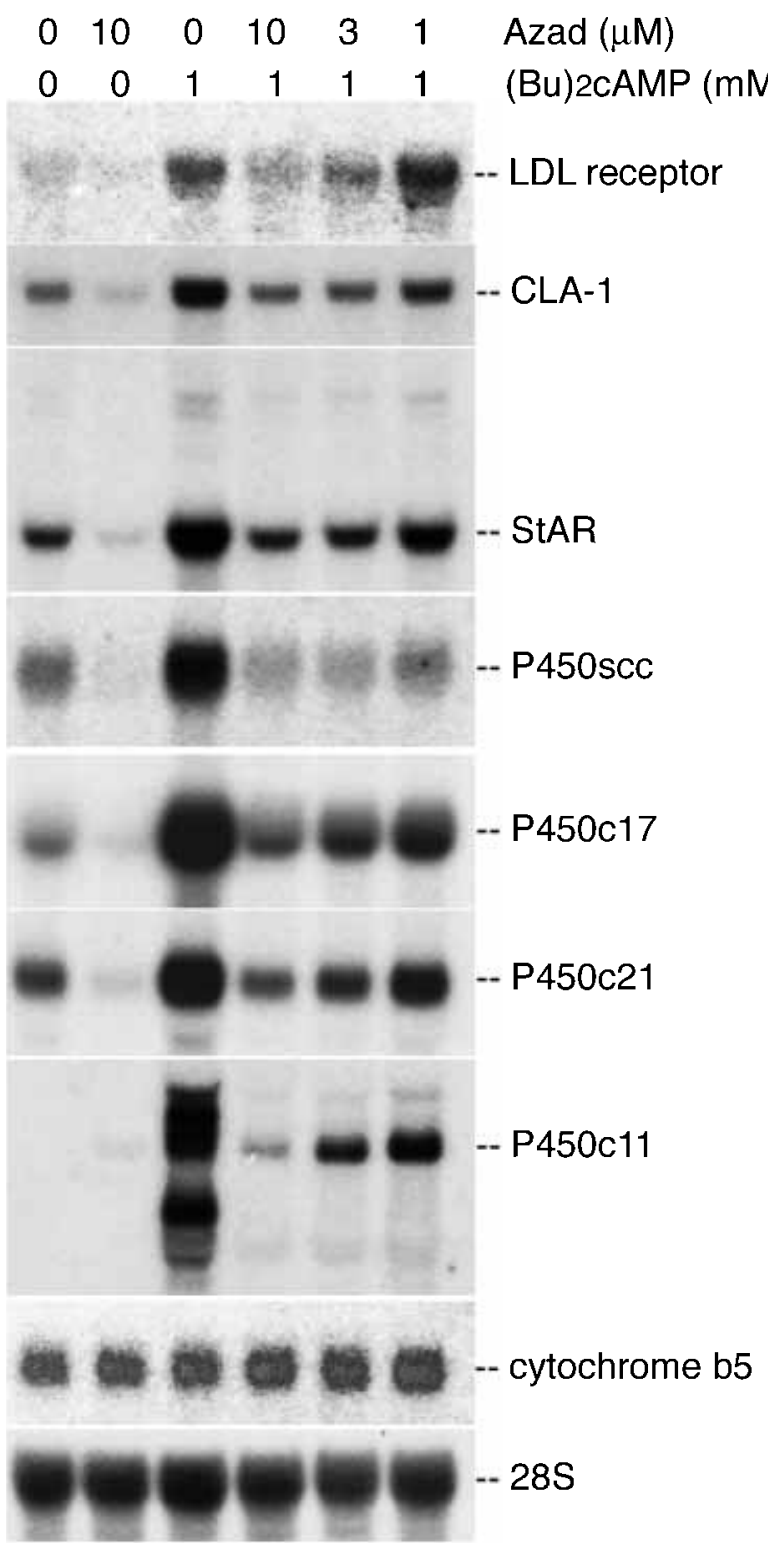

Figure 3 (b).

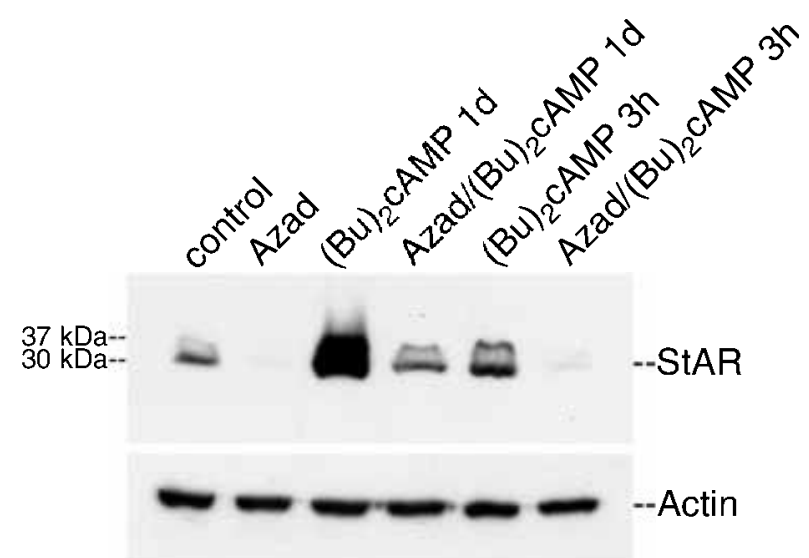

Figure 3 (c).

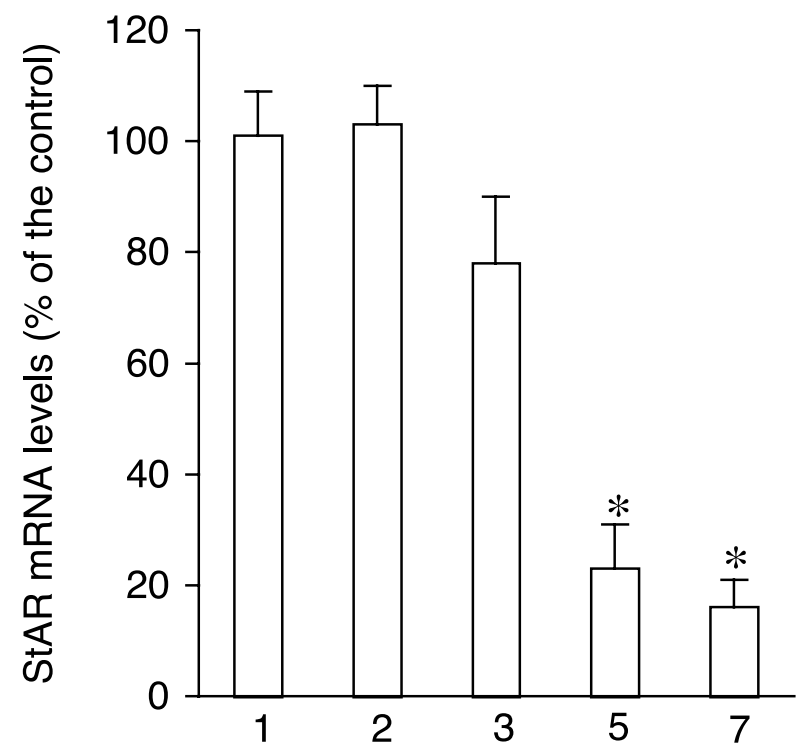

\section{Days for Azad treatment}

Figure $3(d)$.

Figure 3 (a) Effect of Azad (10 $\mu \mathrm{M}$ for 7 days) and $(\mathrm{Bu})_{2} \mathrm{CAMP}$ ( $1 \mathrm{mM}$ for 1 day) treatment on the mRNA expression of LDL receptor (LDL-R), CLA-1, StAR, P450 scc (scc), P450c17 (c17), P450c21 (c21), P450c11 (c11) and cytochrome b5 (b5) genes in H295R cells. The bars represent the relative mRNA expression (mean \pm S.E.) in eight separate experiments when the control is adjusted to 100 . ${ }^{\star} P<0.01$ compared with the control and $\# P<0.01$ compared with the $(\mathrm{Bu})_{2}$ cAMP group. (b) Representative Northern blot analysis showing mRNA expression of steroidogenic genes regulated by Azad ( 7 days) and $(\mathrm{Bu})_{2} \mathrm{CAMP}$ ( 1 day) treatment at the indicated concentrations in H295R cells. The Northern blotting was performed with $20 \mu \mathrm{g}$ cytoplasmic RNA on each lane. 28S ribosomal RNA expression is shown to demonstrate equal loading. (c) Representative Western blot analysis showing StAR expression in H295R cells treated with Azad (10 $\mu \mathrm{M}$ for 7 days) and/or (Bu) ${ }_{2} \mathrm{cAMP}$ (1 mM for 1 day or $3 \mathrm{~h}$ ). Actin (all isoforms) was used as a loading control. (d) Time-dependent effect of Azad (10 $\mu \mathrm{M})$ treatment on StAR mRNA accumulation in H295R cells. Each column represents relative StAR mRNA level (mean \pm S.E. of four experiments) with the control values adjusted to 100 . ${ }^{\star} P<0.05$ compared with the control. 


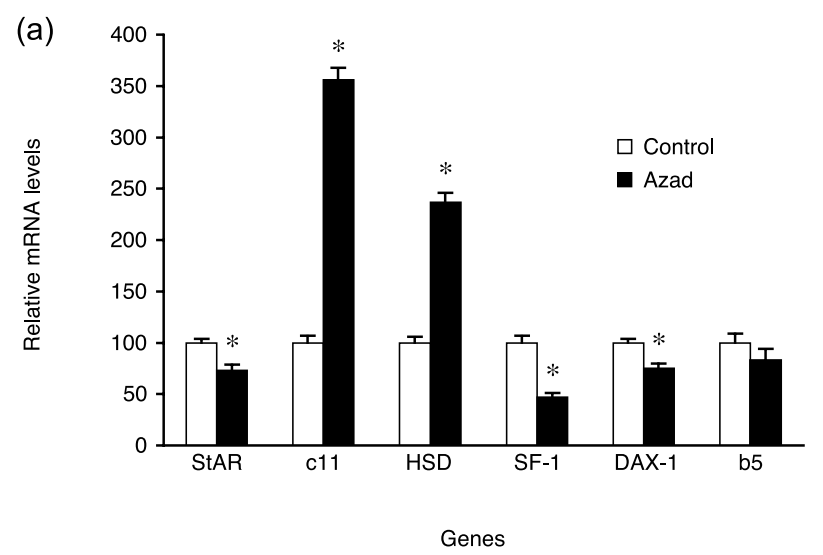

(b)
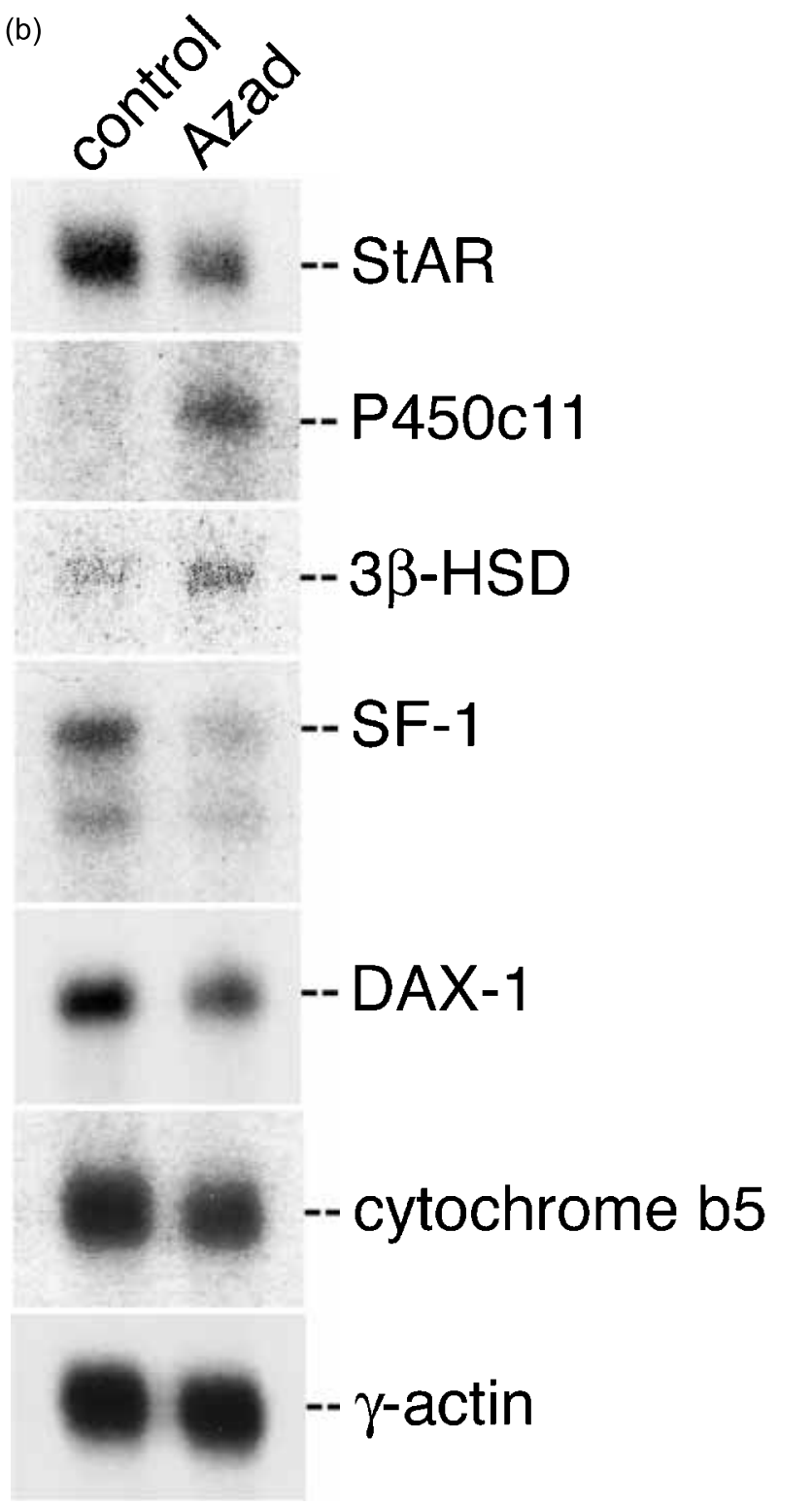

$(\mathrm{Bu})_{2} \mathrm{cAMP}$-induced $\mathrm{P} 450 \mathrm{cl} 1$ and $3 \beta$-HSD gene expression (Fig. 4a). Since the basal expression level of these two genes was too low to be clearly shown by Northern blotting using cytoplasmic RNA, the effect of Azad on these two genes was also studied by Northern blotting with polyA ${ }^{+}$RNA (Fig. 4b). These effects of Azad treatment were dose and time dependent (data not shown). In contrast, cytochrome b5 mRNA was not affected by Azad treatment (Figs $3 a$ and $b$, and 4).

Since the expression of many steroidogenic genes was cooperatively down-regulated by Azad treatment, and there are no putative $\mathrm{CpG}$ islands in the promoter regions of these genes, we hypothesize that these genes were not directly regulated by Azad. We therefore studied the expression of SF-1 and DAX-1 genes, which have many CpG sites in their promoter areas. As shown in Fig. 4, the expression of both SF-1 and DAX-1 genes was inhibited by Azad treatment. Since DAX-1 was previously reported to be regulated by SF-1 (Parker \& Schimmer 1997, Peter \& Dubuis 2000), we concentrated on the mechanism of SF-1 regulation. To study if Azad treatment affects the methylation status of the SF-1 promoter, we used PCR-based methylation analysis. As shown in Fig. 5, the methylation degree of the HpaII recognition site(s) in the SF-1 gene promoter region decreased after Azad treatment, as demonstrated by the weaker PCR product band for the Azad-treated sample than for the control after HpaII digestion of the cell line DNA. We also used several other methylationsensitive restriction enzymes, including AvaII, FspI, HaeII and HhaI. Their restriction sites were unmethylated in H295R cells and thus Azad treatment had no effect on their methylation status (data not shown).

Figure 4 (a) Effect of Azad ( $10 \mu \mathrm{M}$ for 7 days) on the mRNA expression of StAR, P450c11 (c11), 3及-HSD (HSD), SF-1, DAX-1 and cytochrome b5 (b5) genes in H295R cells. The data were from three Northern blots prepared with either polyA ${ }^{+}$or cytoplasmic RNA. The bars represent the relative mRNA expression (mean \pm S.E.) when the control is adjusted to 100 . ${ }^{\star} P<0.05$ compared with the control. (b) Representative Northern blot showing mRNA expression of indicated genes in H295R cells treated with or without Azad (10 $\mu \mathrm{M}$ for 7 days). The Northern blot was prepared with $3 \mu \mathrm{g}$ polyA+ RNA on each lane; $\gamma$-actin mRNA expression was used to control mRNA loading. 
(a)

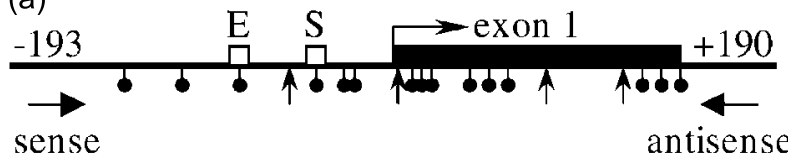

(b)

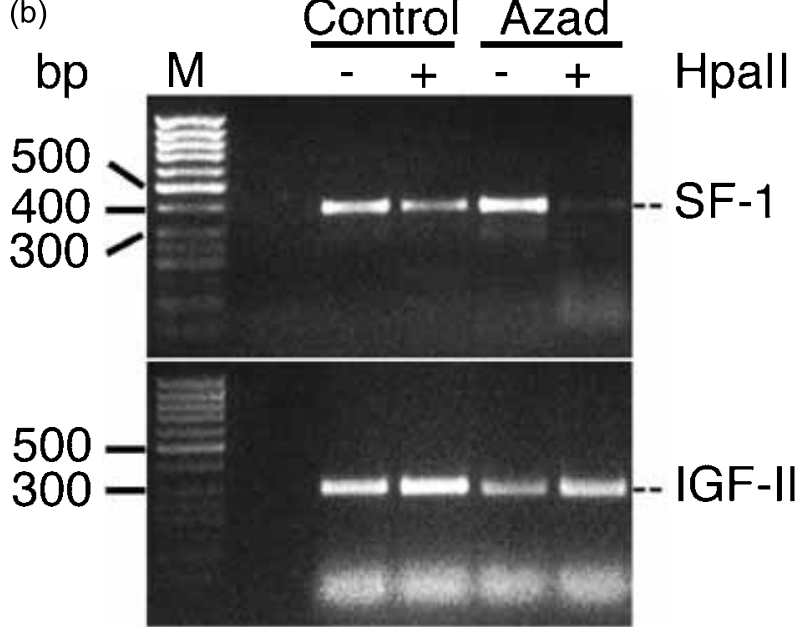

Figure 5 (a) Diagram of the methylation analysis of the SF-1 promoter region. The SF-1 transcription start site (bent arrow), exon 1 (black bar), CpG sites (filled circles), Hpall cutting sites (vertical arrows), primer locations (horizontal arrows), E box (E) and Sp1-binding site $(S)$ are illustrated. The nucleotide numbers $(-193$ and +190$)$ are counted from the transcription start site. (b) Representative PCR-based methylation analysis of the SF-1 promoter region in H295R cells treated with or without Azad (10 $\mu \mathrm{M}$ for 7 days). M, DNA molecular weight marker; +, digested with Hpall; -, undigested. Note the reduced DNA methylation degree (the fainter SF-1 band after digestion by Hpall) in Azad-treated cells compared with the control ones. The PCR product of the IGF-II gene serves as an internal control of DNA amount (no Hpall recognition site within the amplified IGF-II gene fragment).

To find out whether the machinery for modulating gene transcription by DNA methylation exists in H295R cells, we immunostained cultured H295R cells with a MeCP2 antibody. While weakly to moderately positive staining was detected in most nuclei in both control cultures and Azad-treated cells, a minority of cells showed strong staining. These strongly stained nuclei were generally smaller in size than the others, and they were more frequently observed in the control than in the Azad-treated cultures (Fig. 6). Western blotting analysis also showed expression of the $75 \mathrm{kDa}$ MeCP2 protein in H295R cells and Azad

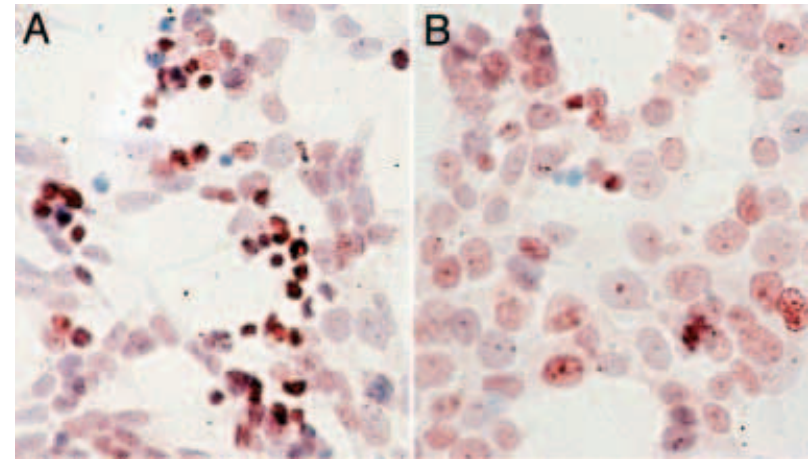

Figure 6 Immunocytochemical staining of MeCP2 in H295R cells. H295R cells were treated with or without Azad for 7 days at the concentration of $10 \mu \mathrm{M}$, and then analyzed with anti-MeCP2 antibody. Magnification, $\times 200$. Note the condensed nuclear staining in the control cells (a), and enlarged nuclei in the Azad-treated cells $(b)$.

treatment had no effect on the MeCP2 protein level (data not shown).

\section{Discussion}

In this study, we demonstrated that DNA methylation is implicated in the regulation of cellular proliferation and steroidogenesis in adrenocortical H295R cells. The presence of the methyl-CpG-binding protein MeCP2 in H295R cells confirms that a functional machinery to mediate the effect of DNA methylation is available in these cells (Lewis et al. 1992). Using incorporated BrdU as a proliferation marker, we reproduced the previous finding that inhibition of DNA methylation by Azad reduces H295R cell proliferation (Gao et al. 2002). In addition, we confirmed the result by direct cell counting. This reduced proliferation rate is unlikely to be due to potential general toxicity of Azad, since Azad increased coordinately the expression of $\mathrm{p} 57^{\mathrm{KIP} 2}$ (this study), p21 (data not shown) and H19 (Gao et al. 2002) RNAs in this cell line. This increased expression of cyclin kinase inhibitors and a tumor suppressor may lead to the inhibition of H295R cell proliferation by blocking the cell cycle mainly to the $\mathrm{G}_{2} / \mathrm{M}$ phase. Furthermore, the reduction of proliferation was accompanied by increased cortisol secretion during Azad treatment. Azad treatment caused three types of modulation in the expression of steroidogenic genes. First, it reduced basal and 
$(\mathrm{Bu})_{2} \mathrm{cAMP}$-induced expression of most steroidogenic genes, including LDL receptor, CLA-1, StAR, P450 scc, P450c17 and P450c21 genes. Secondly, for some genes, such as $\mathrm{P} 450 \mathrm{c} 11$ and $3 \beta$-HSD, it increased their basal expression, but inhibited their $(\mathrm{Bu})_{2} \mathrm{cAMP}-$ induced expression. The third type of modulation concerned the cytochrome b5 gene, which did not change its expression in response to Azad treatment. The basal expression of the first type of gene was usually high, easily detectable by Northern blotting with cytoplasmic RNA. After treatment with Azad alone, the abundant expression of these genes was reduced, but still allowed basal steroidogenesis. It is also possible that, despite the reduced gene expression, the enzyme activities of these genes were not reduced significantly during Azad treatment; dissociation of steroidogenesis and StAR gene expression has been described previously in different steroidogenic cells (King et al. 2000, Gambaryan et al. 2003). However, the basal expression of $\mathrm{P} 450 \mathrm{cll}$ and $3 \beta$-HSD genes in untreated cells was very low, almost undetectable by Northern blotting with cytoplasmic RNA. The low expression levels of these genes might limit the basal biosynthesis of cortisol in untreated cells, as reported in human fetal adrenals (Voutilainen et al. 1991, Staels et al. 1993). Steroidogenesis is thus directed via the $\Delta^{5}$-steroid pathway, leading to the production of DHEA and DHEA-S, which are the major steroid products of this cell line. The basal expression level of the $\mathrm{P} 450 \mathrm{cll}$ and $3 \beta$-HSD genes was increased by Azad, resulting in increased cortisol biosynthesis. Interestingly, the global genomic methylation level is gradually reduced with aging (Richardson 2003), which is accompanied by slightly increased basal serum cortisol concentration (Ferrari et al. 2001). Whether this age-related change in DNA methylation is involved in the regulation of steroidogenic gene expression is not clear. However, the interpretation of this study should be cautious, since H295R cells originated from an adrenocortical carcinoma, which often have aberrant methylation status (Gao et al. 2002). Steroidogenesis in adrenocortical tumors is usually abnormal (Dackiw et al. 2001, Ng \& Libertino 2003). Whether DNA methylation is directly implicated in aberrant steroidogenesis in adrenal tumors remains to be clarified.

There are several ways in which Azad might regulate the expression of the steroidogenic genes in H295R cells. Previous reports suggested that the expression of some steroidogenic enzyme genes could be directly regulated by DNA methylation in certain $\mathrm{CpG}$ sites, although their promoter areas have no typical CpG islands (Szyf et al. 1990, Hornsby et al. 1991, 1992). In addition to a direct change of promoter methylation status affecting gene expression, Azad may indirectly regulate steroidogenic gene expression by modulating transcription factors or signal transduction pathways. Generally, more than half of the genes induced by Azad treatment were supposed to be induced by an indirect effect (Karpf \& Jones 2002). Since not all steroidogenic genes have typical CpG islands in their promoters, indirect regulation of these genes by Azad is likely. If this is the case, SF-1 is a good candidate since its promoter region has a CpG island, and the transcription of the main steroidogenic genes as well as that of the DAX-1 gene has been reported to be regulated by SF-1 (Mesiano \& Jaffe 1997, Peter \& Dubuis 2000). The present study showed that SF-1 is down-regulated by Azad treatment. The important transcription elements E box CACGTG and GG-rich Spl-binding site in the SF-1 promoter area (Parker \& Schimmer 1997, Woodson et al. 1997, Scherrer et al. 2002) within our PCR-amplified region but not recognized by HpaII, may be the target sites for the effects of DNA methylation (Griswold \& Kim 2001). It was previously reported that most of the Azad down-regulated genes may contain a typical $\mathrm{CpG}$ island in their promoter regions in the human LD419 fibroblast cell line (Liang et al. 2002). However, the inhibitory effect of Azad on SF-1 expression could also be secondary to an induction of a negative modulator of SF-1 transcription, since inhibition of promoter methylation is usually associated with activation of gene expression (Zingg \& Jones 1997, Jaenisch \& Bird 2003). In addition, since the modulation of steroidogenic gene expression was not identical, there could be several factors/signal pathways simultaneously implicated during Azad treatment. For example, IGF-II expression is down-regulated by Azad treatment in this cell line (Gao et al. 2002) and IGF-II can preferentially affect biosynthesis of some steroid hormones probably by regulating steroidogenic enzyme gene expression in human adrenocortical cells (Fottner et al. 1998). Interestingly, the Azad-upregulated genes - such as H19, p57 KIP2, $3 \beta$-HSD and P450c1 1 - are generally expressed at 
low levels, whereas the down-regulated IGF-II and some steroidogenic genes are expressed at high levels in adrenocortical carcinomas (Gao et al. 2002, this study). Therefore, the changed expression ratio of these genes during Azad treatment is likely to play a role in H295R cell proliferation and steroidogenesis.

In summary, our results showed that cell proliferation and both basal and $(\mathrm{Bu})_{2} \mathrm{cAMP}-$ stimulated cortisol secretion and steroidogenic gene expression are regulated by the DNA methylation inhibitor Azad in H295R cells, suggesting that DNA methylation is implicated in the regulation of human adrenocortical cell proliferation and steroidogenesis.

\section{Acknowledgements}

Ms Merja Haukka and Ms Minna Heiskanen are thanked for their technical assistance.

\section{Funding}

This work was financially supported by the Academy of Finland, the Sigrid Jusélius Foundation, the Jalmari and Rauha Ahokas Foundation, and Kuopio University Hospital.

\section{References}

Christenson LK \& Strauss JF $3^{\text {rd }} 2001$ Steroidogenic acute regulatory protein: an update on its regulation and mechanism of action. Archives of Medical Research 32 576-586.

Christman JK 2002 5-Azacytidine and 5-aza-2'-deoxycytidine as inhibitors of DNA methylation: mechanistic studies and their implications for cancer therapy. Oncogene 21 5483-5495.

Dackiw AP, Lee JE, Gagel RF \& Evans DB 2001 Adrenal cortical carcinoma. World Journal of Surgery $25914-926$.

Ferrari E, Cravello L, Muzzoni B, Casarotti D, Paltro M, Solerte SB, Fioravanti M, Cuzzoni G, Pontiggia B \& Magri F 2001 Age-related changes of the hypothalamic-pituitary-adrenal axis: pathophysiological correlates. European Fournal of Endocrinology 144 319-329.

Fottner C, Engelhardt D \& Weber MM 1998 Regulation of steroidogenesis by insulin-like growth factors (IGFs) in adult human adrenocortical cells: IGF-I and, more potently, IGF-II preferentially enhance androgen biosynthesis through interaction with the IGF-I receptor and IGF-binding proteins. Foumal of Endocrinology 158 409-417.

Gambaryan S, Butt E, Marcus K, Glazova M, Palmetshofer A, Guillon G \& Smolenski A 2003 cGMP-dependent protein kinase type II regulates basal level of aldosterone production by zona glomerulosa cells without increasing expression of the steroidogenic acute regulatory protein gene. Fournal of Biological Chemistry $27829640-29648$.
Gao ZH, Suppola S, Liu J, Heikkilä P, Jänne J \& Voutilainen R 2002 Association of H19 promoter methylation with the expression of H19 and insulin-like growth factor-II genes in adrenocortical tumors. Fournal of Clinical Endocrinology and Metabolism 87 1170-1176.

Griswold MD \& Kim JS 2001 Site-specific methylation of the promoter alters deoxyribonucleic acid-protein interactions and prevents follicle-stimulating hormone receptor gene transcription. Biology of Reproduction 64 602-610.

Hornsby PJ, Yang L, Raju SG \& Cheng CY 1991 Changes in gene expression and DNA methylation in adrenocortical cells senescing in culture. Mutation Research 256 105-113.

Hornsby PJ, Yang L, Raju SG, Maghsoudlou SS, Lala DS \& Nallaseth FS 1992 Demethylation of specific sites in the 5 '-flanking region of the CYP17 genes when bovine adrenocortical cells are placed in culture. DNA and Cell Biology 11 385-395.

Ilvesmäki V \& Voutilainen R 1991 Interaction of phorbol ester and adrenocorticotropin in the regulation of steroidogenic $\mathrm{P} 450$ genes in human fetal and adult adrenals. Endocrinology 128 1450-1458.

Jaenisch R \& Bird A 2003 Epigenetic regulation of gene expression: how the genome integrates intrinsic and environmental signals. Nature Genetics 33 (Suppl) 245-254.

Karpf AR \& Jones DA 2002 Reactivating the expression of methylation silenced genes in human cancer. Oncogene $\mathbf{2 1}$ 5496-5503.

King SR, Walsh LP \& Stocco DM 2000 Nigericin inhibits accumulation of the steroidogenic acute regulatory protein but not steroidogenesis. Molecular and Cellular Endocrinology 166 147-153.

Letellier M, Lévesque A, Daigle F \& Grant A 1996 Performance evaluation of automated immunoassays on the Technicon Immuno I System. Clinical Chemistry 42 1695-1701.

Lewis JD, Meehan RR, Henzel WJ, Maurer-Fogy I, Jeppesen P Klein F \& Bird A 1992 Purification, sequence, and cellular localization of a novel chromosomal protein that binds to methylated DNA. Cell 69 905-914.

Li Y, Nagai H, Ohno T, Yuge M, Hatano S, Ito E, Mori N, Saito H \& Kinoshita T 2002 Aberrant DNA methylation of p57KIP2 gene in the promoter region in lymphoid malignancies of B-cell phenotype. Blood 100 2572-2577.

Liang G, Gonzales FA, Jones PA, Orntoft TF \& Thykjaer T 2002 Analysis of gene induction in human fibroblasts and bladder cancer cells exposed to the methylation inhibitor 5-aza-2'-deoxycytidine. Cancer Research 62 961-966.

Liu J, Heikkilä P, Kahri AI \& Voutilainen R 1996 Expression of the steroidogenic acute regulatory protein mRNA in adrenal tumors and cultured adrenal cells. Fournal of Endocrinology 150 43-50.

Liu J, Kahri AI, Heikkilä P \& Voutilainen R 1997 Ribonucleic acid expression of the clustered imprinted genes, p57 KIP2, insulin-like growth factor II, and H19, in adrenal tumors and cultured adrenal cells. Fournal of Clinical Endocrinology and Metabolism $\mathbf{8 2}$ 1766-1771.

Liu J, Heikkilä P, Meng QH, Kahri AI, Tikkanen MJ \& Voutilainen R 2000 Expression of low and high density lipoprotein receptor genes in human adrenals. European Fournal of Endocrinology 142 677-682.

Mesiano S \& Jaffe RB 1997 Developmental and functional biology of the primate fetal adrenal cortex. Endocrine Reviews 18 378-403.

Miller WL, Auchus RJ \& Geller DH 1997 The regulation of 17,20 lyase activity. Steroids 62 133-142.

Ng L \& Libertino JM 2003 Adrenocortical carcinoma: diagnosis, evaluation and treatment. Fournal of Urology 169 5-11.

Parker KL \& Schimmer BP 1997 Steroidogenic factor 1: a key determinant of endocrine development and function. Endocrine Reviews $18361-377$. 
Peter M \& Dubuis JM 2000 Transcription factors as regulators of steroidogenic P-450 enzymes. European Fournal of Clinical Investigation 30 (Suppl 3) 14-20.

Prokhortchouk E \& Hendrich B 2002 Methyl-CpG binding proteins and cancer: are MeCpGs more important than MBDs? Oncogene $215394-5399$.

Ramchandani S, MacLeod R, Pinard M, von Hofe E \& Szyf M 1997 Inhibition of tumorigenesis by a cytosine-DNA, methyltransferase, antisense oligodeoxynucleotide. PNAS 94 684-689.

Richardson B 2003 Impact of aging on DNA methylation. Ageing Research Reviews 2 245-261.

Scherrer SP, Rice DA \& Heckert LL 2002 Expression of steroidogenic factor 1 in the testis requires an interactive array of elements within its proximal promoter. Biology of Reproduction $\mathbf{6 7}$ $1509-1521$.

Staels B, Hum DW \& Miller WL 1993 Regulation of steroidogenesis in NCI-H295 cells: a cellular model of the human fetal adrenal. Molecular Endocrinology 7 423-433.

Szyf M, Milstone DS, Schimmer BP, Parker KL \& Seidman JG 1990 Cis modification of the steroid 21-hydroxylase gene prevents its expression in the Y1 mouse adrenocortical tumor cell line. Molecular Endocrinology 4 1144-1152.
Voutilainen R, Tapanainen J, Chung B, Matteson KJ \& Miller WL 1986 Hormonal regulation of P450 scc (20,22-desmolase) and P450c17 (17 $\alpha$-hydroxylase/17,20-lyase) in cultured human granulosa cell. Fournal of Clinical Endocrinology and Metabolism 63 202-207.

Voutilainen R, Ilvesmäki V \& Miettinen PJ 1991 Low expression of $3 \beta$-hydroxy-5-ene steroid dehydrogenase gene in human fetal adrenals in vivo; adrenocorticotropin and protein kinase G-dependent regulation in adrenocortical cultures. Fournal of Clinical Endocrinology and Metabolism 72 761-767.

Wade PA 2001 Methyl CpG-binding proteins and transcriptional repression. BioEssays 23 1131-1137.

Woodson KG, Crawford PA, Sadovsky Y \& Milbrandt J 1997 Characterization of the promoter of SF-1, an orphan nuclear receptor required for adrenal and gonadal development. Molecular Endocrinology 11 117-126.

Zingg JM \& Jones PA 1997 Genetic and epigenetic aspects of DNA methylation on genome expression, evolution, mutation and carcinogenesis. Carcinogenesis 18 869-882.

\section{Received 19 August 2004} Accepted 3 September 2004 